\title{
EVALUATION OF THE FEEDING VALUE OF TWO TROPICAL CEREAL STRAWS, MAIZE STOVER, RICE STRAW AND THEIR BOTANICAL FRACTIONS BY NYLON AND MOBILE BAG TECHNIQUE
}

\author{
Dyness M. Mgheni ${ }^{1 *}$; Edith E. Ndemanisho'; T. Hvelplund ${ }^{2}$ and M. R. Weisbjerg ${ }^{2}$. \\ ${ }^{1}$ Department of Animal Science and Production, Sokoine University of Agriculture, \\ P.O. Box 3004, Chuo Kikuu, Tanzania. \\ ${ }^{2}$ Danish Institute of Agricultural Sciences, Department of Animal Nutrition and Physiology, \\ Research Centre Foulum, P.O. Box 50, DK - 8830 Tjele, Denmark.
}

\begin{abstract}
Degradability characteristics of dry matter (DM), protein free DM (PFDM) and nitrogen $(N)$ were estimated in maize stover, rice straw and their botanical fractions using the nylon bag technique. True intestinal digestibility of the intact feed protein (TID) was also estimated using the mobile bag technique. The results indicated that cereal straws and their botanical fractions have substantial variation in the extent and rate at which DM, PFDM and $N$ were degraded in the rumen. The protein values of Total amino acid absorbed from the small intestine (AAT), Protein balance in the rumen (PB) and TID ranged from 49 to $81 \mathrm{~g} \mathrm{~kg}^{-1} \mathrm{DM}$, in PBV from-89 to - $61 \mathrm{~g} \mathrm{~kg}^{-1} \mathrm{DM}$ and TID of 34 to 69 percent DM in both straws and their botanical fractions. The predicted dry matter intake (DMI) value for whole maize stover was slightly higher $\left(5.2 \mathrm{~kg} \mathrm{DM} \mathrm{d}^{-1}\right)$ than whole rice straw $4.9 \mathrm{~kg}$

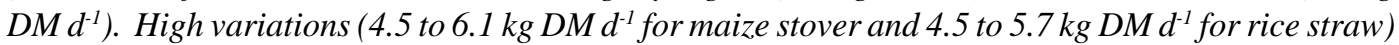
were observed within the two cereal straw botanical fractions. It was concluded that the two cereal straws are of very low feeding value and to increase their production potential improvement method strategies like chemical treatment and/or supplementation are inevitable.
\end{abstract}

Key words: Tropical cereal straws, ruminants, nylon bag, AAT-PBV, prediction of intake.

\section{INTRODUCTION}

Various methods have been advocated for evaluating tropical feedstuffs (Preston, 1995). Incubation of test feeds in nylon bags in the rumen of fistulated animals have been used to evaluate not only the extent, but also the rate at which feed fractions are degraded in the rumen (Kimambo et al., 1994; Shem et al., 1995). Also the mobile bag technique has been used to measure intestinal digestibility of undegraded dietary protein (Mgheni et al., 1994) and intact feed protein (Kimambo et al., 1994). Similar evaluation methods have been used by other workers elsewhere for nylon bag technique (Weisbjerg et al., 1990; Stensig et al.,1994) and for mobile bag technique (Hvelplund et al., 1992). The results have been used not only to rank feedstuffs into their potential feeding value but also to develop models that have been used to predict how much the animal can eat (Ørskov et al., 1988; Kimambo et al., 1994; Madsen et al., 1994; Shem et al., 1995). The authors concluded that the nylon bag technique, is a powerful tool that can be used to evaluate the potential feeding value of tropical forages. The technique has been the basis of the AAT-PBV protein evaluation system (Madsen et al., 1995) and "Fill" values based on rumen pool size of DM (Madsen et al., 1994) and NDF (Stensig et al., 1994). The parameters have been used with acceptable precision to predict voluntary feed intake of DM and NDF. This is an added information about the feeding value of the feed that gives approximately how much the animal can eat assuming physical limitation of intake. Considering the importance of cereal crop residues being among the major animal feeds available in the tropics for ruminant animals during the dry season, the information can be used for proper planning and feeding strategies. An experiment was therefore conducted to evaluate the feeding value of maize stover and rice straw and their botanical fractions using these different evaluation methods.

\section{MATERIALSANDMETHODS}

\section{Animals, feeds and feeding}

Three rumen fistulated dry Friesian cows fed $5.4 \mathrm{~kg}$ DM of good quality hay (156 g crude protein $(\mathrm{CP}) \mathrm{kg}^{-1} \mathrm{DM}$ ) plus $2.6 \mathrm{~kg} \mathrm{DM}$ concentrate $\left(184 \mathrm{~g} \mathrm{CP} \mathrm{kg}^{-1} \mathrm{DM}\right)$ per cow per day 
were used. Minerals and vitamins were provided sufficiently for microbial activity (ARC, 1990). The animals were fed twice per day at 0900 and $1600 \mathrm{~h}$ and had free access to water.

Maize stover from maize crop var. STAHA was collected from the field on the same day the crop was being harvested. Samples of maize stover were separated into their different botanical fractions viz: leaves, leaf sheaths, husks, stems and panicles. Rice straw var. SUPA was collected also from the field within one week after rice grain was harvested. The straw was separated into different botanical fractions, viz: leaves, leaf sheaths, stems and panicles. All samples were air dried at room temperatures and ground to pass through a $2.5 \mathrm{~mm}$ sieve, packed into labelled nylon bags and air-freighted to Denmark (Danish Institute of Agriculture Sciences) where the experiment was conducted.

\section{Rumen degradability}

Rumen degradability of dry matter (DM), protein free dry matter (PFDM) and nitrogen (N) were determined using the nylon bag technique in similar procedure described by Mgheni et al. (1996). Incubation time intervals used were $0,8,16,24,48,96,144$, and $192 \mathrm{~h}$. Samples were treated in a stomacher (Model 400 Lab Blender) before analysis to remove microbial contamination. True intestinal digestibility of the intact feed protein was determined by the mobile bag technique according to the methods described by Hvelplund et al. (1992).

\section{Chemical analysis}

Dry matter (DM), ash and $\mathrm{N}$ contents were determined according to the procedure outlined by AOAC (1991). The neutral detergent fibre (NDF), acid detergent fibre (ADF), acid detergent lignin (ADL) and acid insoluble ash (AIA) in the straws were determined according to the procedures outlined by Goering and Van Soest (1970). The water insoluble ash (WIA) in all samples was determined according to the procedure described by Mgheni et al. (1996).

\section{Calculations}

\section{Description of the degradation profile}

The degradation profile of protein for each forage was described using the mathematical model of Ørskov and McDonald (1979) with lag time as suggested by Dhanoa (1988):

$p=a+b\left(1-e^{-c(t-t o)}\right)$ for $t>t_{0}$ (Model 1) where,

$\mathbf{p}=$ degraded fraction at time $\mathbf{t}$

a $=$ water soluble fraction

b $=$ insoluble, potentially degradable fraction

c $=$ degradation rate constant $\left(\mathrm{h}^{-1}\right)$

$\mathbf{t}=$ incubation time (h)

$\mathbf{t}_{\mathbf{0}}=$ lag time

The data were analysed using the SAS program PROC NLIN (SAS 1990) for estimation of degradation constants. Parameters of Model (1) were bound only to accept $\mathbf{t}_{\mathbf{o}} \geq 0$

Digestible carbohydrate (DCHO), actual intestinal digestibility of intact feed protein, and effective degradability

The digestible carbohydrate (DCHO), the actual intestinal digestibility of intact feed protein (TID), effective degradability (ED) of DM, PFDM and N were estimated using equations described by Mgheni et al. (1996).

\section{Estimated AAT-PBV values and true digestibility of protein (TID)}

AAT-PBV values were calculated according to the equations of Madsen et al. (1995) for protein evaluation system. The TID was calculated using the equation given by Hvelplund et al. (1992).

\section{Estimation of rumen physical fill - Fill (day)}

Assuming that a feedstuff will remain in the rumen until it is either degraded or has passed out of the rumen, the physical fill - Fill (day) of a given feedstuff fraction in the rumen can be calculated according to Madsen et al. (1994) and lag time included as:

$$
\text { Fill }=\frac{1-a}{k} \times\left(1-e^{-k t_{t o}}\right)+\frac{1-a-b}{k} \times e^{-k t_{o}}+\frac{b}{c+k} \times e^{-k t_{o}}
$$

where $\mathbf{a}, \mathbf{b}$ and $\mathbf{c}$ are parameters from Model $\mathbf{1 ,} \mathbf{t}_{\mathbf{0}}$ is the lag time (h) and $\mathbf{k}$ is outflow rate $\left(\mathrm{h}^{-1}\right)$.

\section{Prediction of intake}

Predicted intake was calculated assuming a rumen capacity (rumen pool) of $7 \mathrm{~kg}$ total DM measured in mature nonpregnant Holstein Friesian X Boran heifers weighing on average $270 \mathrm{~kg}$ live body weight (Mgheni et al., 1996). Assuming $1.5 \mathrm{~kg}$ DM to be microbial matter, gives $5.5 \mathrm{~kg}$ DM microbial free DM rumen capacity. The potential intake 
Evaluation of the Feeding Value of Two Tropical Cereal Straws, Maize Stover, Rice Straw and their Botanical Fractions by Nylon and Mobile Bag Technique

$\left(\mathrm{kg} \mathrm{DM} \mathrm{d}^{-1}\right)$ of the cereal straws and their botanical fractions can be estimated assuming a physical limitation of the reticulo-rumen capacity according to Madsen et al. (1994) as:

\section{DMI $\left(\operatorname{kg~DM~d}^{-1}\right)=$}

\section{Rumen capacity (kg DM)}

Fill (day) $\quad$........... (Model 3)

RESULTS

\section{Chemical composition}

Chemical composition of maize stover and rice straw and their botanical fractions are shown in Table 1 . The $\mathrm{N}$ content $\left(\mathrm{g} \mathrm{kg}^{-1} \mathrm{DM}\right)$ in maize stover ranged from 3.2 (stems) to 9.1 (panicles) and from 3.5 to 5.7 for rice straw stems and leaves respectively. The NDF, ADF and ADL $\left(\mathrm{g} \mathrm{kg}^{-1} \mathrm{DM}\right)$ respectively, were higher in whole maize stover (746.5; $492.8 ; 68.6)$ than whole rice straw $(635.7 ; 421.1 ; 46.3)$. Their botanical fractions were not analysed because the samples taken to Denmark were exhausted. The HCL fat content ( $g$ $\mathrm{kg}^{-1} \mathrm{DM}$ ) in maize stover ranged from 13.7 (husks) to 24.8 (leaves) and from 10.8 to 19.9 in rice straw stems and leaves respectively. Total ash content in rice straw and its botanical fractions were higher than that of maize stover and its botanical fractions.

Table 1. Chemical composition of tropical cereal straws (maize stover and rice straw) and their botanical fractions.

\begin{tabular}{lllll}
\hline \multicolumn{5}{c}{ Feed fractions $\left(\mathrm{g} \mathrm{kg}^{-1} \mathrm{DM}\right)^{1}$} \\
Feed type & \multicolumn{4}{l}{} \\
\cline { 2 - 5 } & $\mathrm{N}$ & HCL fat & Total ash & WIA \\
\hline Maize stover: & & & & \\
Whole & 5.3 & 16.6 & 81.8 & 41.2 \\
Leaves & 7.5 & 24.8 & 143.7 & 97.1 \\
Leaf shealths & 4.6 & 14.2 & 80.6 & 54.5 \\
Husks & 3.5 & 13.7 & 33.1 & 5.4 \\
Stem & 3.2 & 14.4 & 75.4 & 14.5 \\
Panicles & 9.1 & 20.3 & 49.9 & 32.4 \\
Rice Straw: & & & & \\
Whole & 4.9 & 16.5 & 196.1 & 147.8 \\
Leaves & 5.7 & 19.9 & 222.7 & 211.4 \\
Leaf sheaths & 3.6 & 14.8 & 209.8 & 165.9 \\
Stems & 3.5 & 10.8 & 173.6 & 90.7 \\
Panicles & 5.6 & 12.3 & 98.8 & 69.6 \\
\hline
\end{tabular}

${ }^{1}$ Other analysis made were NDF, ADF and AIA $\left(\left(\mathrm{g} \mathrm{kg}^{-1} \mathrm{DM}\right)=\right.$ $746.5,68.6$ and 39.4 respectively for whole maize stover; 635.7, $421.1,46.3$ and 159.9 respectively for whole rice straw.

\section{Rumen degradation characteristics}

The estimated degradation characteristics for maize stover, rice straw and their botanical fractions are given in Table 2 . Values for soluble fraction (a) for DM and PFDM for whole rice straw and stems were higher compared to other botanical fractions and whole maize stover and its botanical fractions. Soluble fraction (a) for $\mathrm{N}$ were more or less similar except for maize stover panicles that showed the highest value. More or less similar values were observed in both whole cereal straws. The insoluble, but potentially degradable fraction (b) for DM and PFDM were more or less similar while that for $\mathrm{N}$ were lower than that of DM and PFDM. The rate constants (c) were very low in both fractions. The degradability characteristics for DM, PFDM and $\mathrm{N}$ were not estimated in rice straw panicles, as Model (1) failed to handle the data even when lag time was included as suggested by Dhanoa (1988) as the PROC NLIN failed to converge. The $\mathrm{N}$ degradability values for rice straw panicles were 23.5, 33.8, 29.9, 31.3, 21.2, 34.3, 43.4 and $48.8 \% \mathrm{DM}$ for $0,8,16,24,24,48,96,144$ and $192 \mathrm{~h}$ respectively. The values were therefore omitted in this study for further calculations. Effective degradability (ED) for $\mathrm{DM}, \mathrm{PFDM}$ and $\mathrm{N}$ for maize stover, rice straw and their botanical fractions are given in Table 3. The ED for DM, PFDM and $\mathrm{N}$ decreased with increasing outflow rates.

True intestinal digestibility (TDI), total amino acid absorbed from the small intestine (AAT) and protein balance in the rumen (PBV)

True intestinal digestibility of intact feed protein (TID) of maize stover, rice straw and their botanical fractions are shown in Table 4. The TID was higher in rice straw and its botanical fractions than in maize stover except for maize stover panicles. The calculated digestible carbohydrate (DCHO), AAT and PBV values are also given in Table 4. The DCHO values were more or less similar in maize stover and rice straw and their botanical fractions except for maize stover stems, which had the lowest value. The AAT had more or less similar values in both straws and their botanical fractions. The PBV was negative for both straws and their botanical fractions.

\section{Calculated Fill (day) and predicted dry matter intake (DMI)}

Fill (day) values calculated using Model (6) , predicted DMI (PDMI) in kg DM d ${ }^{-1}$ calculated using Model (7) and expressed as percentage of live body weight are given in Table 5. As expected maize stover stems had the highest Fill value compared to maize stover leaves, which had the lowest value. This is contrary to rice straw where stems 
Table 2. Degradability constants for dry matter (DM), protein free dry matter (PFDM) and nitrogen (N) for maize stover and rice straw and their botanical fractions.

\begin{tabular}{|c|c|c|c|c|c|c|c|c|c|c|c|c|}
\hline \multicolumn{13}{|c|}{ Degradability constants (\% DM) } \\
\hline & \multicolumn{3}{|c|}{$\mathbf{a}$} & \multicolumn{3}{|c|}{$\mathbf{b}$} & \multicolumn{3}{|c|}{ Rates constant c $(\% \mathrm{~h}-1)$} & \multicolumn{3}{|c|}{0.04} \\
\hline $\begin{array}{l}\text { Type of } \\
\text { Straw }\end{array}$ & $\overline{\mathbf{D M}}$ & PFDM & $\mathbf{N}$ & DM & PFDM & $\mathbf{N}$ & $\overline{D M}$ & PFDM & $\mathbf{N}$ & DM & PEDM & $\mathbf{N}$ \\
\hline $\begin{array}{l}\text { Maize } \\
\text { stover: }\end{array}$ & & & & & & & & & & & & \\
\hline Whole & 11.80 & 11.00 & 33.10 & 67.81 & 68.49 & 33.78 & 2.53 & 2.77 & 2.13 & 0.50 & 1.21 & 12.87 \\
\hline Leaves & 15.60 & 14.40 & 37.70 & 71.56 & 73.39 & 43.34 & 3.09 & 2.95 & 2.31 & 2.90 & 1.59 & 9.60 \\
\hline Leaf sheaths & 13.20 & 12.23 & 32.22 & 68.02 & 69.04 & 35.20 & 2.13 & 2.18 & 1.48 & 0.00 & 0.00 & 0.00 \\
\hline Husks & 9.40 & 8.80 & 32.97 & 77.93 & 78.88 & 37.94 & 3.42 & 3.55 & 1.90 & 4.09 & 5.10 & 31.03 \\
\hline Stems & 13.74 & 13.49 & 27.21 & 54.96 & 55.61 & 28.36 & 2.09 & 2.10 & 0.29 & 0.00 & 0.00 & 48.00 \\
\hline Panicles & 12.90 & 11.30 & 42.98 & 61.25 & 63.11 & 25.11 & 2.33 & 2.35 & 2.78 & 1.17 & 1.60 & 0.00 \\
\hline Rice straw: & & & & & & & & & & & & \\
\hline Whole & 17.19 & 16.40 & 29.27 & 74.05 & 63.39 & 77.66 & 1.29 & 2.62 & 0.39 & 0.00 & 2.56 & 4.13 \\
\hline Leaves & 14.90 & 14.10 & 31.35 & 80.96 & 82.85 & 50.17 & 1.37 & 1.37 & 1.38 & 2.01 & 1.54 & 39.26 \\
\hline Leaf sheaths & 14.20 & 13.60 & 23.32 & 78.57 & 77.25 & 29.18 & 1.12 & 1.26 & 0.19 & 2.61 & 3.59 & 8.41 \\
\hline Stems & 20.90 & 20.70 & 25.16 & 65.94 & 66.03 & 99.42 & 1.97 & 2.06 & 0.28 & 0.06 & 0.60 & 5.60 \\
\hline Panicles & - & & - & - & - & - & - & - & - & - & - & - \\
\hline
\end{tabular}

Table 3. Effective degradability (ED) of dry matter (DM), protein free dry matter (PFDM) and nitrogen (N) for maize stover and rice straw and their botanical fractions

\begin{tabular}{|l|l|l|l|l|l|l|l|l|l|l|l|l|}
\hline \multicolumn{10}{|c|}{ Effective degradability (\%) at outflow rate (\%) of: } \\
\hline & \multicolumn{3}{|c|}{0.01} & \multicolumn{3}{|c|}{0.02} & \multicolumn{3}{c|}{0.03} & \multicolumn{3}{c|}{0.04} \\
\hline $\begin{array}{l}\text { Type of } \\
\text { Straw }\end{array}$ & DM & PFDM & $\mathrm{N}$ & DM & $\begin{array}{l}\text { PFD } \\
\text { M }\end{array}$ & $\mathrm{N}$ & DM & PFDM & $\mathrm{N}$ & DM & PEDM & $\mathrm{N}$ \\
\hline Maize stover: & & & & & & & & & & & & \\
\hline Whole & 60.16 & 60.73 & 53.31 & 49.30 & 49.83 & 46.57 & 42.37 & 42.72 & 42.64 & 37.56 & 37.71 & 40.12 \\
\hline Leaves & 68.10 & 68.36 & 65.19 & 56.57 & 56.79 & 56.88 & 48.86 & 49.12 & 51.84 & 43.35 & 43.66 & 48.51 \\
\hline Leaf sheaths & 59.50 & 59.59 & 53.21 & 48.29 & 48.27 & 47.18 & 41.46 & 41.32 & 43.84 & 36.85 & 36.61 & 41.72 \\
\hline Husks & 67.30 & 67.28 & 51.21 & 54.74 & 54.36 & 42.92 & 46.15 & 45.49 & 38.78 & 39.93 & 39.05 & 36.51 \\
\hline Stems & 50.92 & 51.15 & 31.14 & 41.83 & 41.96 & 28.58 & 36.31 & 36.38 & 27.80 & 32.61 & 32.63 & 27.49 \\
\hline Panicles & 55.28 & 54.87 & 61.45 & 45.12 & 44.32 & 57.58 & 38.77 & 37.73 & 55.06 & 34.43 & 33.21 & 53.28 \\
\hline Rice straw: & & & & & & & & & & & & \\
\hline Whole & 58.88 & 61.14 & 50.50 & 46.20 & 30.58 & 41.14 & 39.43 & 43.79 & 37.31 & 35.23 & 39.07 & 35.23 \\
\hline Leaves & 60.76 & 61.24 & 51.04 & 46.51 & 46.74 & 40.73 & 38.79 & 38.88 & 36.23 & 33.95 & 33.96 & 34.04 \\
\hline Leaf sheaths & 54.68 & 55.08 & 41.86 & 41.00 & 41.33 & 32.56 & 33.98 & 34.06 & 29.15 & 29.79 & 29.58 & 27.40 \\
\hline Stems & 64.61 & 64.91 & 45.97 & 53.50 & 53.83 & 36.22 & 46.99 & 47.13 & 32.43 & 42.61 & 42.64 & 30.43 \\
\hline Panicles $\dagger$ & - & - & - & - & - & - & - & - & - & - & - & - \\
\hline
\end{tabular}

\$ PROC NLIN failed to converge. 
Table 4. True intestinal digestibility (TID) of intact feed, protein balance in the rumen protein, and total amino acid (AAT) for maize stover and rice straw and their botanical fractions.

\begin{tabular}{lllll}
\hline $\begin{array}{l}\text { Type of } \\
\text { straw }\end{array}$ & TDI $^{1}(\%$ & $\begin{array}{l}\text { DCHO } \\
(\mathrm{g} \mathrm{kg}-1 \mathrm{DM})\end{array}$ & $\begin{array}{l}\mathrm{PBV}^{2} \\
(\mathrm{~g} \mathrm{~kg}-1 \mathrm{DM})\end{array}$ & $\begin{array}{l}\mathrm{AAT}^{2} \\
(\mathrm{~g} \mathrm{~kg}-1 \mathrm{DM})\end{array}$ \\
\hline
\end{tabular}

\section{Maize stover:}

$\begin{array}{lllll}\text { Whole } & 48.6 & 434.59 & -77.45 & 67.40 \\ \text { Leaves } & 38.4 & 484.79 & -86.30 & 81.44 \\ \text { Leaf sheaths } & 33.8 & 437.03 & -77.91 & 64.82 \\ \text { Husks } & 39.1 & 498.57 & -88.94 & 66.98 \\ \text { Stem } & 34.4 & 344.59 & -61.48 & 49.45 \\ \text { Panicles } & 43.3 & 392.40 & -69.74 & 78.03\end{array}$

Rice Straw:

\begin{tabular}{lcccc} 
Whole & 48.9 & 435.36 & -77.62 & 65.90 \\
Leaves & 41.5 & 431.49 & -76.49 & 68.68 \\
Leaf sheaths & 38.3 & 354.14 & -63.17 & 52.07 \\
Stems & 69.4 & 439.34 & -78.37 & 60.75 \\
Panicles & - & - & - & - \\
\hline
\end{tabular}

${ }^{1}$ Used to calculate the intestinal digestibility of the undegraded protein (Madsen et al., 1995) as given in Model (3).

${ }^{2}$ Estimated using the AAT-PBV protein evaluation system (Madsen et al. 1995) as given in Model (4) and (5).

Table 5. Predicted dry matter intake (PDMI) of maize stover, rice straw and their botanical fractions.

\begin{tabular}{lll}
\hline Type of straw Fill (day) & PDMI 1 & PDMI2 (\% \\
& $($ kg DM d-1) & Live (Body \\
& Weight) \\
\hline
\end{tabular}

\section{Maize stover:}

$\begin{array}{llll}\text { Whole } & 1.06 & 5.21 & 1.93 \\ \text { Leaves } & 0.9 & 6.08 & 2.25 \\ \text { Leaf sheaths } & 1.07 & 5.11 & 1.89 \\ \text { Husks } & 0.94 & 5.83 & 2.16 \\ \text { Stem } & 1.21 & 4.51 & 1.67 \\ \text { Panicles } & 1.14 & 4.81 & 1.78\end{array}$

\section{Rice Straw:}

\begin{tabular}{lccc} 
Whole & 1.12 & 4.91 & 1.82 \\
Leaves & 1.11 & 4.94 & 1.83 \\
Leaf sheaths & 1.23 & 4.47 & 1.65 \\
Stems & 0.98 & 5.69 & 2.11 \\
Panicles & - & - & - \\
\hline
\end{tabular}

${ }^{1}$ Predicted using Model (7) according to Madsen et al. (1994). ${ }^{2}$ Live body weight $(270 \mathrm{~kg})$ was assumed to be equal to that of mature non-pregnant Friesian x Boran heifers as measured by Mgheni et al. (1998). had the lowest Fill value compared to the rest of its botanical fractions. The PDMI expressed as a percentage of live body weight is lower than the conventional 3.5 percent. There was no marked difference in PDMI between maize stover and rice straw and their botanical fractions although maize stover leaves showed the highest PDMI and rice leaf sheaths the lowest PDMI.

\section{DISCUSSION}

Chemical constituents of the two tropical cereal straws are in agreement with those reported for rice straw and their botanical fractions (Bainton et al., 1991); maize husks and maize stover whole (Kimambo et al., 1994). As expected, total ash content in rice straw and its botanical fractions were higher than that of maize stover and its botanical fractions due to high silica content in the later. Similar trend was observed for water insoluble ash (WIA) and acid insoluble ash (AIA).

The $\mathrm{N}$ content for both cereal straws was found to be very low. Such low values of $\mathrm{N}$ are known to depress DM and N degradability and result in low intake in rice straw (Djajanegara and Doyle, 1989; Shem et al., 1995). Djajanegara and Doyle (1989) indicated that low levels of $\mathrm{N}$ decrease microbial activities and that intake of roughages is limited when $\mathrm{N}$ content is $<10 \mathrm{~g} \mathrm{~kg}^{-1} \mathrm{DM}$. Also the high NDF, ADF and ADL values (Table 1) in these cereal straws may result into low intake.

The low water soluble fraction (a), high insoluble but potentially degradable fraction (b) and low rate of degradation (c) for DM, PFDM and N (Table 2) for these cereal straws suggest that they will have a high Fill value and thus low intake (Table 5). This is in agreement with other findings by Kimambo et al., (1994) who reported low feeding value of tropical roughages. High potential degradable fraction, $\mathbf{b}$ (Table 2) for DM, PFDM and N may suggest that proper supplementation may increase potential rumen degradability. Dhanoa (1988) suggested that when dealing with low degradable feeds and in the presence of large lag times (Table 2) one should remember to take samples over a longer period of incubation time above $72 \mathrm{~h}$ or higher depending on the feed sample. This is to make sure that the asymptote is reasonably defined otherwise fitting of Model (1) may not be possible. Although long incubation time was used in this study (192 h), Model (1) could not handle the data for $\mathrm{N}$ for rice straw panicles (Table 2) and therefore its values were removed when the effective degradability and Fill values were calculated. This can be explained by too long lag time (Table 2) and low degradation for $\mathrm{N}$ for these feedstuffs. This may suggest that it is useless to analyse for $\mathrm{N}$ 
(especially degradation constants) in such feedstuffs and their $\mathrm{N}$ values should therefore be considered as negligible or close to zero.

The decreased ED with increasing outflow rate (Table 3) clearly demonstrates that actual value of outflow rate is necessary for proper estimate of ED. Intestinal digestibility of the intact feed protein estimated by the mobile bag technique was generally very low (Table 4 ). This was also reported by Kimambo et al. (1994) for tropical feeds. The results suggest that utilisation of tropical dietary protein is only possible through an increased degradation in the rumen and the conversion of this degraded protein into microbial protein. Intestinal digestibility of the undegraded dietary protein is of great importance for estimating the protein value of feeds (Hvelplund et al., 1992 and Mgheni et al., 1994). This implies that the value of the undegraded feed protein of these straws is almost negligible and that is due to high cell wall content (Kimambo et al., 1994) that normally binds this feed fraction. As suggested by the AAT/PBV protein evaluation system (Madsen et al., 1995) the digestibility of undegraded protein in straw should be assumed to be equal to zero.

Bainton et al. (1991) reported variation in the nutritive value of straw species, between varieties and also between their botanical fractions in rice straws. Walli et al. (1988) found that in rice straw varieties the leaf fraction was slightly less digestible than the stems. This may suggest that if generous feeding is advocated the animals will not be able to differentiate the more digestible fraction in rice straw. The general trend found in this study is that these cereal straws are low in $\mathrm{N}$ (Table 1), negative PBV, low AAT values (Table 4) and low digestibility (Table 2 and 3 ) resulting into low predicted DMI (Table 5). This may suggest that in order to increase their production potential, strategies like chemical treatment and/or supplementation and probably be generous feeding are inevitable.

The predicted DMI (Table 5) varied between the two cereal straws and within their botanical fractions. This variation is due to differences in chemical composition (Table 1) and degradation constants (Table 2). The results are, however, in close agreement with those reported by Kimambo et al. (1994) using similar models. Precision of using degradation characteristics to predict DMI has been tested for tropical feedstuffs in cattle with high $\mathrm{r}=0.90$ and 0.93 for DMI and digestible DMI respectively (Shem et al., 1995). Similar work has earlier been reported by Ørskov et al. (1988) based on degradation characteristics and intake studies of different varieties of straws by cattle with a precision of $r$ $=0.88$.
Predicted DMI especially, may tempt one to suggest that if animals are fed generously ( $>3 \mathrm{x}$ ad libitum) animals may be able to select the most nutritious part of the straw (e.g. maize stover leaves and rice straw stems) and achieve reasonable production potential. However, the animal may not differentiate between stems and leaves of rice straw. Also problem will arise on the economies of collection of enormous amounts of these straws and how to dispose the huge amount of left over by the animals. This is an area that needs further study.

\section{CONCLUSION}

It was concluded that the feeding value (in terms of chemical composition, rumen digestibility and PDMI) maize stover, rice straw and their botanical fractions were found to be very low. The $\mathrm{N}$ was lower $\left(4.9 \mathrm{~g} \mathrm{~kg}^{-1}\right.$ for whole rice straw and $5.3 \mathrm{~g} \mathrm{~kg}^{-1}$ for whole maize stover) than the recommended value $\left(7.0 \mathrm{~g} \mathrm{~kg}^{-1}\right)$ below which intake is depressed. Some of their botanical fractions were found to be of better nutritive value (e.g. $\mathrm{N}=9.1$ and $7.5 \mathrm{~g} \mathrm{~kg}^{-1}$ and 5.6 and $5.7 \mathrm{~g} \mathrm{~kg}^{-1}$ for both maize stover and rice straw panicles and leaves respectively) than whole plants. As for other botanical fractions their $\mathrm{N}$ values were so low that for most practical purposes their $\mathrm{N}$ values can be negligible or assumed to be zero. It can further be concluded that due to low N, rumen digestibility and thus high "Fill values" resulted in PDMI lower than that, which can support animal production.

\section{ACKNOWLEDGEMENTS}

The authors are grateful for the financial support by EU Contract No. $\mathrm{TS}_{2} 0248 \mathrm{UK}$.

\section{REFERENCES}

ARC, (1990). Agricultural Research Council. The Nutrient Requirement of Ruminant Livestock. $4^{\text {th }}$ Edition. CAB International Wallingford Oxon, UK: pp 73-310.

Bainton, S.J.; Plumb, V.E.; Juliano, B.O.; Perez, C.M.; Roxas, D.B.; Khush, G.S.; de Jesus, J.C. and Gomez, K.A. (1991). Variation in the nutrition-al value of rice straw. Animal Feed Science and Technology, 34:261-277.

Dhanoa, M. S. (1988). On the analysis of dacron bag data for low degradabil-ity feeds. Grass and Forage Science, 43:441-444.

Djajanegara, A. and Doyle, P.T. (1989). Urea supplementation compared with pre-treatment. Effect on intake, digestion and live-weight change by sheep fed rice straw. Animal Feed Science and Technology, 25:21-36. 

and their Botanical Fractions by Nylon and Mobile Bag Technique

Goering, H.K. and Van Soest, P.J. (1970). Forage Fibre Analysis. USA, Department of Agriculture. Agriculture Research Services. Agriculture Handbook No 379, pp 1-20.

Hvelplund, T.; Weisbjerg, M.R. and Andersen, L.S. (1992). Estimation of the true digestibility of rumen undegraded dietary protein in the small intestine of ruminants by the mobile bag technique. Acta Agricul-turae Scandinavica Supplement. 42:34-49.

Kimambo, A.E.; Weisbjerg, M.R.; Hvelplund, T. and Madsen, J. (1994). Feeding value of some tropical feeds evaluated by the nylon bag technique: In Proceedings of the Workshop on integrated Livestock/Crop Production Systems in the small scale and communal farming systems in Zimbabwe. (Edited by Mutisi, C.; Gomez, M.; Madsen, J. and Hvelplund, T.). UZ/RVAU/NIAS Publication. pp 5868.

Madsen, J.; Stensig, T.; Weisbjerg, M.R. and Hvelplund, T. (1994). Es-timation of the physical fill of feedstuffs in the rumen by the in sacco degradation characteristics. Livestock Production Science. 39:4347.

Madsen, J., Hvelplund, T., Weisbjerg, M.R., Bertilsson, J., Olsson, I., Spörndly, R., Harstad, O. M., Volden, H., Tuori, M., Varvikko, T., Huhtanen, P., Olafsson, B.L. (1995). The AAT/PBV protein evaluation system for ruminants. A revision. Norwegian Journal of Agricultural Sciences. Supplement No. 19 (1995) 37 pp.

Mgheni, D. M.; Hvelplund, T. and Weisbjerg, M.R. (1994). Intestinal Digestibility of Rumen Undegraded Dietary Protein from Tropical Roughages Estimated by the Mobile Bag Technique. Acta Agriculturae Scandinavica, Section A.. Animal Science. 44:230235.

Mgheni, D.M; T. Hvelplund and M.R. Weisbjerg . (1996). Rumen degradability of dry matter and protein in tropical grass and legumes forages and their protein values expressed in the AAT-PBV protein evaluation system. In: Ndikumana, J. and de Leeuw, P., 1996 (Eds). Sustainable Feed Production and Utilization for Smallholder Livestock Enterprises in SubSaharan Africa. Proceedings of the Second African Feed Resources Network (AFNET). HarareZimbabwe, 6-10, December, 1993. pp 77-84.
Ørskov, E.R.; Reid, G.W. and Kay, M. (1988). Prediction of intake by cattle from degradation characteristics of roughages. Animal Production. 46:29-34.

Ørskov, E.R. and McDonald, I. (1979). The stimation of protein degradability in the rumen from incubation measurements weighted according to rate of passage. Journal of Agricultural Science. Cambridge. 92: 499503.

Preston, T.R. (1995). Tropical animal feeding. A manual for research workers. FAO Animal Production and Health Paper. 126:181-277.

Shem, M.N., Ørskov, E.R. and Kimambo, A.E. (1995). Prediction of voluntary dry-matter intake, digestible dry-matter intake and growth rate of cattle from the degradation characteristics of tropical foods. Animal Science. 60:65-74.

SAS (1990). Statistical Analysis Systems. SAS Institute INC, SAS Language Reference Version 6. Cary, NC. 6.12 Release: 1043 pp.

Stensig ,T.; Weisbjerg, M.R., Madsen, J. and Hvelplund, T. (1994). Estimation of voluntary feed intake from in sacco degradability and rate of passage of DM or NDF. Livestock Production Science. 39:49-52.

Walli, T.K.; E.R. Ærskov and P.K. Bhargava (1988). Rumen degradation of straw. Botanical fractions of two rice straw varieties of ammonia treatment. Animal Production 46:347-352.

Weisbjerg, M.R.; Bhargava, P.K.; Hvelplund, T. and Madsen, J. (1990). Use of degradation curves in feed evaluation. 679. Report from the National Institute of Animal Science. Denmark. 33 pp. 